International Journal of Engineering \& Technology, $10(2)(2021) 220-231$
International Journal of Engineering \& Technology
SPC
Website: www.sciencepubco.com/index.php/IJET
Research paper

\title{
Online brand, opportunities, realities and challenges for SMEs. Fresh recruits, a solution or new kind of orienteering challenge?
}

\author{
Ari Happonen ${ }^{1 *}$, Laura Manninen ${ }^{2}$, Ulla Santti $^{3}$, Muralindran Mariappan ${ }^{3}$ \\ ${ }^{1}$ LUT School of Engineering Science, LUT University, Lappeenranta, Finland \\ ${ }^{2}$ Laurafilmaa, Helsinki, Finland \\ ${ }^{3}$ Bio and circular economy, Savonia University of Applied Sciences, Kuopio, Finland \\ ${ }^{4}$ Robotics \& Intelligent Systems, Universiti Malaysia Sabah, Sabah, \\ *Corresponding author E-mail: ari.happonen@lut.fi
}

\begin{abstract}
The research produced understanding how fresh employer's private social media brand can be beneficial for a company brand. It was also found that the companies' own brand image was not inline with their set expectations for usage of employer social media brand and skills. For the given challenge, literary review on the means for improving the situation of financially limited SMEs was carried out. Overall research data is based on literature review and interview data with students and company executives. Based on interviews, companies are looking for applicants who have an "individual brand" with visible personality. In the interviews, companies perceived "brand" to be connected to distinguishable individuality and presence of a personality. The study objectivity is to stimulate discussion on SME brand structuring as well as impact of individual brands into the SME brand building efforts with practical action options. Individual brands should be taken into account in recruitment and special attention needs to be put to the following orientation process, social media usage and processes of brand construction, with the new recruits. Whether the company has guidelines for social media actions or not, the public presence of the employee connects their brand with the company online brand, both in good and bad. Clear strategies and objectives for (new) employees how to connect their individual brand to company brand building is needed to be given from companies to their employees. This will also require guidelines for behavior in social media for employees, when communicating trough social media profiles, which could be connected back to the employing organization. Lastly, we studied expectations and beliefs of young recruits and companies into the key factors at the recruitment process, revealing mis alignment between the students and companies' views.
\end{abstract}

Keywords: Brand; Digitalization; Employment; Individual brand; Organizational brand; Recruitment; Small and medium-sized enterprises; SME; Social media.

\section{Introduction}

The challenges of the SME companies brand building efforts to be supported by their recruits was found in background work of this research. The project work focused on SME sized companies and municipality related health services work practice orientation processes. Alongside with this research, interviews were conducted at SMEs and previously mentioned companies that had high efficiency in recruiting process. The interviews revealed that the requirements of companies for their current employees, and to be recruit young applicants did not match up together. The researchers had e.g. an assumption, that when a company wants to hire young employees, it is looking for well-trained and educated young people to grow together with the company. At the same time, it was also assumed that the companies' public presence in Internet was in order, which would correspond to the general expectations in current digital age, when outspoken external communication is one of the main success elements for SMEs. It would be obvious, as good visual appearance and renewing of corporate visual identity (CVI), plus openness in public communication, have been proven to give positive effects to identity/image [1]. In general, the strategic activities companies take during the initial phases of the recruitment process and later on in orientation, will have positive implications to the amount of high quality workforce the company can have and keep working with them [2]. As a result of the efficiency of nowadays Internet tools [3], people do put quite a much expectations for companies' visual online appearance and make assumptions about the brand, based on this outlook view. Users look for and expect professional like quality and usability e.g. in the companies own websites, as well as the amount of available content and the generic public do have quite a lot, where to compare to. In brand building sense, when company personnel's individual brands can be linked to a company, one can create positive boost for the organizations brand image. This possibility for added positive brand image creates an idea to "just to purchase" their social media reputation, but in practice, the reputation of the company needs to be re-earned every day and it cannot be constructed and based solely on bought brand visibility. Nowadays, the contend consumers see large quantities of content in daily basis, which makes them ready to notice an artificial and/or misleading content and then quickly dismissed it in comments [4]. 
In this social media visibility and brand connected context, we studied the connection of new recruits, their individual brands and connecting then to company brand building needs. The research was carried out based on data obtained from a literature research and SME presentative interviews. Literature research gave indications on the formation of companies' brands and their different aspects. The interviews provided information on the personal characteristics that companies expect from their employees (that is, the expectations of a particular type of individual brand). In addition, the interviews gave an indication of how companies create their own brands and the way in which workers can influence it as individuals. The aim of the study was to build new understanding on how a company brand is formed, as well as to understand the importance of social media as part of the brand construction process. This was done to support the development of the research subject by examining the views, aspirations and expectations of those companies who have products, services and business operations connected to rapidly changing and developing digitalized local and global client bases.

\section{Research materials and methods}

The research is based on literature review and company presentative interviews. All companies chosen for interviewing were either grown fast within the last 3 years timeframe. The results of the interviews were quantified and analysed in context of recruitment and the connection it had to company's future online brand building efforts. The qualitative part of the interview included: opinions, approach descriptions and ideologies, and the models of which the companies said they were following. By comparing the future skill needs the companies named in the interviews to the best growth practice models presented in the literature, the research created suggestions for the resource limited SMEs. The research speculates on SMEs possibility to support their company brand growth with help of strong and quickly spreading individual brands. It was also assumed, that those people who could use their personal brands to boost the company brands, would stand out in the job markets. Additionally, individual brand-based marketing risks for company brands were considered too. The research pays an attention to the digitalisation offering companies huge growth potential in business development, plus service and product development side [5-8], digital transformation is changing the way general public participates to company activities and then it extends into social media context as enabler of a fast and affordable large-scale visibility building possibilities.

Representatives from the companies' human resources and managements were selected for interviews, and their views, experiences and corporate ideologies were surveyed regarding to the themes of individual and company brands. Interview time was typically between 30 to 60 minutes and the questions concerned especially hiring new, young employees, and the company's attitude toward using social media as a tool in the recruitment process and in company brand marketing. Total of 14 company personnel interviews were conducted, examining the topic from the point of view of the company brand, and the individual brand of the future employees who apply to the company. Most interviewees were, executives from IT companies, or working in managerial positions in human resources management, either in the lead or in operative management. In addition, one beginning young entrepreneur was interviewed, concerning brand creation, to create a point of reference for companies that have existed for a long time. Besides the companies, students who were just entering working life were also interviewed. The objective of these interviews was to examine if the students' assumptions about the employers' needs and wishes would correspond to what employers look for in new employees, like skills, abilities, personality and so on.

\section{Research materials and methods}

Social media offers a unique marketing opportunity for companies [9], while also providing a tool for direct and nearly uncensored communication with the potential customer base and ways to collaboratively creating of common understanding between different actors [10]. Social media is digital society connected enabler for SMEs in visibility, product marketing and service promotions [11]. Likewise, a small investment is enough to increase company's visibility and spread of their marketing messages for wide audiences. In addition, social media can act as an enabler for easy networking with related businesses and customers [12]. Moreover, content sharing and marketing can be facilitated, and the integration of workers and their networks with daily tasks becomes more efficient. On the other hand, large enough followers / audience is needed to reach so called critical mass to turn social media investments into tangible profits [13]. Even with large social media follower base, capturing markets usually cannot rely solely on it, but from efficiency point of view, social media platforms are one of the most potent marketing tools to complement all other traditional brand promotion solutions and channels. Specially for micro companies and small SMEs, it looks like younger businesses are actually doing relatively better in social media marketing innovations, than their larger counterparts [12]. While many larger companies could learn from these flexible and innovative SMEs, but this sort of technology transfer is not easy, so event the strongest brands must work hard to attain the desired positive visibility [14]. With social media platforms, companies can receive direct feedback from their customers and allows fast reactions to both the negative and the positive comments and feedback. Also, fast actions in social media allows support for a quick spread of a desired message for all new potential customers [11]. When using social media, companies' objectives include enhancing the communication inside the company and between the company and its customers, increasing information and cooperation, decreasing the costs caused by communication, and reaching experts more easily than through traditional channels [15]. The well-known obstacles against social media marketing adoption are lack of resources and skills in sales and marketing, outdated technology, employees change opposition and lack of technical skills [16]. For example, according to BSR Stars [17], organizations were using social media for information sharing, but the Web 2.0based tools were not replacing the predominating traditional solutions (e.g. e-mail) too soon, especially in the marketing and information communication. Specially, the transfer will take some years to happen, if companies do not have enough know-how of different technologies and applications [11], [15]. In short, a specialized person with required technical skills will be needed in marketing to realize and maintain the company's social media visibility [18]. Resource-wise, for micro companies, hiring an employee just for marketing, might not be a possibility, leaving social media activity as secondary priority.

Besides the resources and skills, a employee's right attitude [19] is required for the concretization of the social media marketing related benefits. Employees' attitudes toward social media are mostly defined by how they use social media in their leisure time. Based on [19], people considered social media to be a tool to be used for entertainment purposes, which made them slightly sceptical about the corporate world marketing use. One fear corporate people had was that using social media might distract employees from their work. Optimistic view was that social media is right way to share information and build customer relations [19]. Also, when the skills, tools and attitudes match, the decisive factor is the proper management supports for the employees. Without wholehearted management commitment, company will not gain good results [20]. With commitment, employees can easily contribute to the company goals. Psychological mentoring and supporting by the management increase employee's motivation and commit then to their tasks [21]. And in properly set environment, the company and employees share both the gains and pains together, like in business to business collaboration relationships [22] or between students and teachers, in forced online system teaching, in pandemic times [93]. The skills of management and leading by example 
with incorporation of new technologies to daily operations affects highly to the employees' attitudes toward change [11]. The employee's commitment to the company brand is a form of how employees can feel a sense of belonging to the organization. By helping the employees to see the big picture and by supporting growth with the company, one shall improve attitudes, behaviour and company brand commitment. Overall, good relationships with the employees will support their commitment to the company values [23]. When an employee is aware of the organization's goals, their results and work motivation improve [23].

As a short summary of potential of social media and possible risk mentioned previously, we present the Table 1, based on [11, 15, 19]. When adopting the prospects, companies should take sufficient orientation into account and connect this to proper talent management activities and support tools [24, 25]. In orientation, it is quite easy to make use of the integral game-like elements of social media to make orientation and learning more interesting, exciting, and inspiring [26]. When implementing social media training into new employee training, different learning preferences should be considered, as Nicholson [27] states "By allowing the learner choices, it raises the chance that each learner will find a meaningful connection to the material”.

Table 1: Potential and Challenges of Social Media

\begin{tabular}{ll} 
& Table 1: Potential and Challenges of Social Media \\
\hline Potential & Challenges \\
\hline Communication with customers & Lacking resources \\
Rapid reaction & Outdated technology \\
Direct feedback & Lack of knowledge and skills \\
Fast spreading & Attitudes toward change \\
Low costs & Insufficient support from management \\
Reaching experts & \\
\hline
\end{tabular}

\subsection{The meaning of education and training for a company's success and the brand's visibility}

According to the research by Lyone and Bandura [28], offering learning opportunities to employees makes them stay longer in the company [29]. Thus, training employees supports company's economic viability, but for micro companies, training employees with expensive training courses is not an option. Also, getting all employees to train together at the same time, might present another challenge [28]. The pros of orientation include the fact that it increases group mentality and motivates employees in their work. And for motivation, orientation should include both the employer and the employee. Good orientation is tailored to suit different needs and tasks, and it consists concrete and active learning opportunities. General objectives of training include motivating the employee, learning new skills, participatory leadership and teamwork [28], [30]. For practical implementation, in covid-19 like times, one can e.g. offer video courses and recordings and distance learning via Internet. Access to the training material via Internet, can help the employee to re-train themselves in later times [28]. As summary of good basic training characteristics, we present the following list, based on the synthesis made from Lyone and Bandura [28] and [31]. A good training includes:

- $\quad$ practical and participatory exercises

- clear objectives

- clearly defined roles and responsibilities

- information sharing

- consistently sharing experiences organisational transition and its explanation

- $\quad$ explaining the company brand and teaching the company's strategy

- only short travel distances

- $\quad$ presence of the employer

- concrete learning activities

- flexibility (learner-orientation)

- cost-efficiency

- motivating elements

- $\quad$ promoting group mentality

- $\quad$ easy access to the material also after the orientation

- feedback to employees (often if possible)

\subsection{Customers' trust and networks with social media}

Building collaboration networks and trust in social media with the customers are important elements for company brand growth as satisfied customers will recommend a company, brand and its product \& services. The best recommender is often a peer of a customer [32, 33], which is why marketing in social media is crucial for SMEs visibility. Building networks is based on customers' and partners' trust in the company and its products. People want to stay in warm relations with a reliable partner and keep using their services and products in future. It is also possible to increase one's visibility by creating networks. [34]

According to the research by Hess et al. [35], the reliability of a brand is connected to the quality of the product. This quality is a requirement for building brand reliability, and correspondingly will strengthen the image of the brand. For instance, better made \& durable water bottle packaging is considered of higher quality, more user-friendly and simpler to use [35], which creates the aforementioned experience of the product's quality and brand image. Also, positive sustainability aspects of the products [95], company culture [36] and services/production [96-98], can be highly beneficial for the company brand too, as these aspects of the product and sustainability increasing tools the company might be using [37,94], show that the company is environmentally aware of our global shared responsibility of keeping our nature clean and society viable for future generations.

\subsection{Image, commitment and standing out}

An online brand image builder should observe what attracts the customers most, especially when there is multiple set of similar competing options available [34]. Overall, differentiation is one of the key success elements creating competitive advantage [38]. Basically, without differentiation and good visibility, you will not reach all your possible customers. As part of differentiation and visibility methods [14] states that a full commitment from management to the company strategy is crucial for successful companies. By commitment and by being honest, supporting one's own words with actions and by being fair with full disclosure e.g. about paid marketing and spon- 
sorship content, companies stand out from the competitors [39]. Shortly put, you commit the customers to follow you, and then you tell them how the company can fulfil their needs [14]. A practical example, from satisfied followers of well know social media brander Ville Tolvanen indicates that followers are saying, that the posts are fascinating simply because of their sever honesty [40]. Tolvanen states that a brand strategy should not be a separate part of the company's plan, but instead, it should be a part of the company's overall plan. According to Tolvanen [40], the willingness to produce quality is a strong enabler for a good brand. Tolvanen [40] states that people believe brand experience to be created with advertisements and paint cans. However, in reality brand has to create a "human-like experience that communicates and collects trade and users like a bowl of honey".

\subsection{Small businesses and brand names}

Social media is a tool to build strong relationships [41] and to reach a target audience. With interactivity, speed and effortlessness, social media have become especially popular among micro-enterprises and SMEs. For SMEs, social media, communication, publicity and the channels of brand building are some of the best ways to compete with big companies when they cannot afford to compete in traditional media [42]. Addition to the visibility, new company should be carefully named the visioned brand to increase consumer overall awareness and to strengthen the brand image [43]. In the case of startups and SMEs, Wongpreedee et al. [44] companies generally need younger generations' support for success, and their names should reflect that. Based on McCune [43], brands are generally named with four different main strategies. These are 1) semantic names that provide direct information about the product, 2) people's names, 3) unexpected names, such as Apple or 4) made-up names, such as Xerox. Unexpected brand names mean words used in an unexpected way. Localized names are also commonly used in the Chinese market, where names can be directly connected to places [43]. We also know that many famous brands have been named after family names or cities, such as Nestle or the Bank of China. In the modern world, are suggested to be selected to be short, easy to pronounce, memorable, catchy, and correspondent with the nature of the product and its place in market. This sort of effective brand name increases consumer awareness and strengthens the company's overall image. Best brand names describe the whole product family, not just one product (e.g. iPhone describes the whole family of phones). And finally, in global scale, some names could be problematic with their negative associations. For example, cultural connected associations which should be inspected for the planned name, also considering different pronunciations [43]. In case of rich companies, they could simply try to buy a brand for themselves, as e.g. according to Frey et al. [45], creating a new brand is always a risky and time-consuming endeavour. So, buy a brand might be more cost-efficient, smarter, and less risky tactic than making one from scratch. By Sarkar and Singh [46], brand creation is "a risky venture with a greater chance of failure than success", so continuing developing an existing, strong brand, using buy \& develop strategy has its own promises.

\subsection{Organizational culture, internal and external company image and connection to company brand}

Often young employees mention the work atmosphere or colleagues the best thing at work. Organizational culture is defined as a way the things are done in an organization according to organizational values, predictions, beliefs and norms [47-49] and building an organizational culture which is attractive to young employees would give a competitive advantage for recruitment situations. Organizational culture is also seen as a fostering factor towards innovativeness by information processing capabilities [50]. At the 80's Smircich [51] recognized business organizations cultural quality to include hard-to-change values which defined success or failure. Later Fang [52] criticized Hofstede's static vision of culture, which values determine and prevail the behaviour without taking time into consideration, and presents each culture being a dynamic unique portfolio. Also, Santti et al. [53] found dynamic characteristics in culture changes, explained by business model development projects.

Organizational performance can be enhanced by identifying and adjusting organizational culture towards new desired direction [53-54]. New and unique organizational culture makes the company more attractive. One option for identification utilizes Competing Values Framework tool (CVF) developed by Quinn \& Rohrbaugh on 1981 [55] and visualized in Figure 1. In CVF, each organizational culture is constructed of four values with different recipe: 1) Clan - collaboration: do things together, 2) Adhocracy - creativeness: do things first, 3) hierarchy - control: do things right, and 4) Market - competitiveness: do things fast.

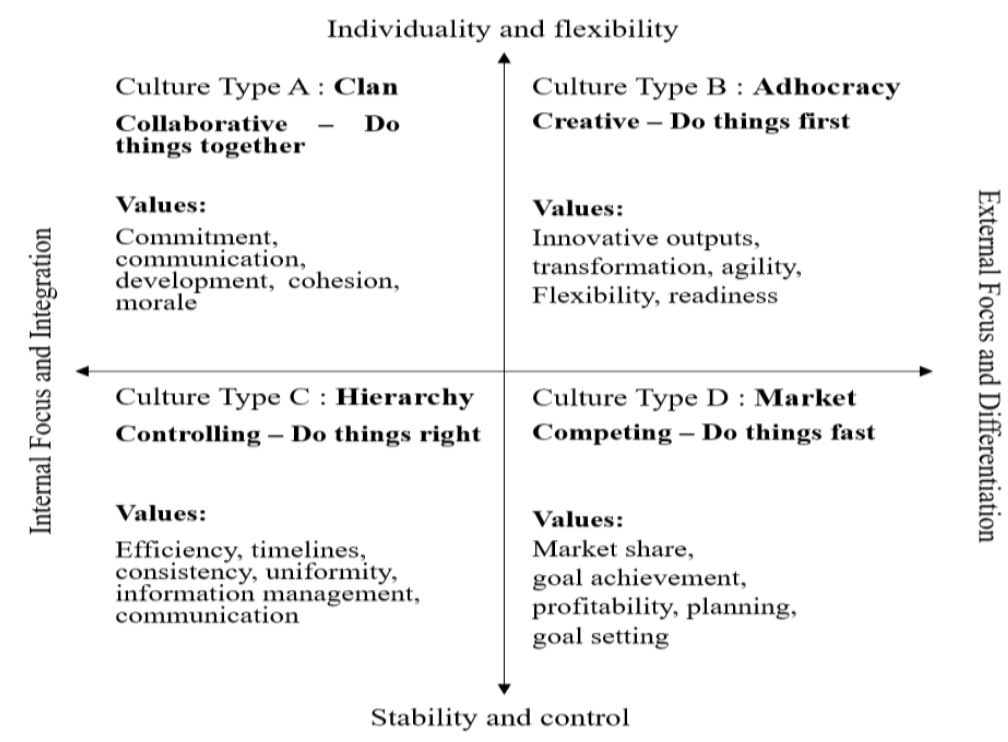

Fig. 1: The CVF Core Value(S). (Adapted From Cameron and Quinn [54]; Yu and Wu [55] and Cameron [56]).

Due to the uniqueness of every organizational culture, it is complex to explain organizational culture consisting employees and managers beliefs and operational models at work. Processes and organizing of labelling and categorizing with use of technology and language and identifying memories, regularizing and routinizing with plausible explanation, which describes actions of people is called critical sense 
making concept [58-59]. Language in one part of cultural development and is considered as a building block of sense making about reality [60] and because the sensemaking is a complex process, individuals may make sense differently of the same language and situation [61]. These non-constant interpretations can lead to challenge if company management tries to drive organizational or cultural change and if it can generate organizational identity issues as well, like counterforce and also Long \& Helms Mills [60] criticized there is a little room for interpretation and rationalization, but still increase of workplace "spirituality" can employ cultural approach to change. Figure 2 shows how each CVF-type includes paradoxes in preferring one force to increase another. Leaders need to find the existence of paradoxes to be able to interpret cognitive behaviours and increase leadership skills in terms of flexibility [62].

The differences between actual behaviour in organization and aspirational image may be caused by organization's self-absorption ability, related to organizational narcissism and reflected by differences between culture and image [63]. For a positive company development, one of the key aspects is the management's commitment [20]. Practically e.g. managements attitude towards younger employees' development ideas and how those ideas are handled in the company. With an aim to increase job attraction and company image in the eyes of young employees, the analysis of organizational culture should also include all unhealthy practices as age-blindness and stereotypes, which affect HRM practices and policies in increasing diversity [64]. Also, the job has to be equal with the given promises in job advertisement and by recruiter. Otherwise young employees start with high motivation but have a hard time to stay in the job [65]. Same like in service marketing, where the communicated promises have to be kept and value delivered for the customers [66].

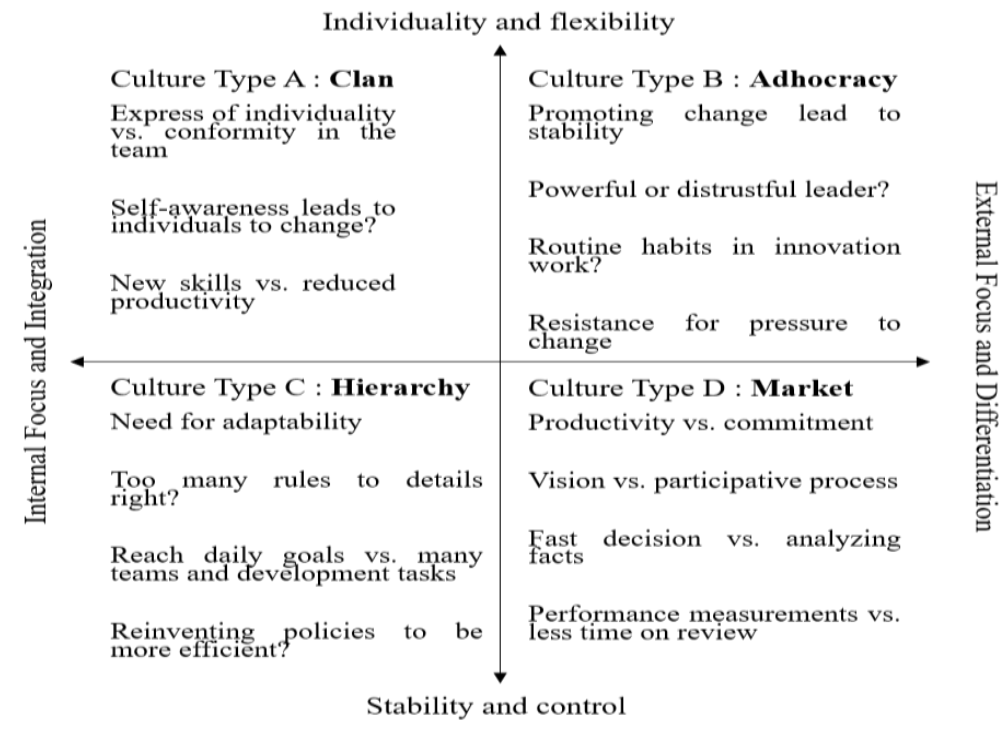

Fig. 2: Competing Values Framework Paradoxes. Adapted from Lavine [62].

One role of the marketing work is to differentiate company and its products from others, to make them tempting for their potential customers, but also to sell ideas for its employees and potential employees. Interrelated concepts of organizational identity "who we are?" and image "who are they?" need to be answered for being able to sync well together [67]. Organizational identity and trust are created and maintained in social interaction and affected by meanings, understanding and interpretation [68]. In this dynamic world, the concept of identity and image are fostered into adaptability, which makes balancing flexible identity a strategic concern for management [69]. To recognize the whole organizational identity in addition to external image, also patterns of behaviour, the organizational culture must be identified [70], which naturally makes taking a certain direction for development activities easier for management.

\section{Interview data and results}

In the following, Table 2 illustrates the interviewees' branches of industry and positions in their companies. The qualitative data was collected both from IT companies and from fast-growing companies that frequently hire new employees. Human resources managements added new insight, with their expert knowledge of hiring processes. The interviews goal was to identify what are the skills and/or existing experience companies looked for in new employees recruit processes. Moreover, how they viewed the meaning or importance of social media in recruitment and as a tool for building the company's image and are these aspects part of their job applicants interview themes. The analysis and research interpretations do give clear regional insight with regard to the companies' experiences and expectations in recruitment in the work market, but because of the geological locality of the sample, the results cannot be generalized globally. Objective of the interviews was to understand the veracity of the claims made in the literature concerning the topic in the context of growing SMEs and to see if it is in line with the current practices.

Table 2: Background and Job Descriptions of the Interviewed Company Representatives

\begin{tabular}{ll}
\hline Branch of industry & Position in the company \\
\hline IT business & Management and marketing, founder \\
IT business, game industry & CEO \\
IT business, software & CEO \\
IT services & Leader of the unit \\
HR & Leader of the unit \\
HR, public administration & Development manager of staff \\
Logistics & Head of HR \\
Logistics & Head of communication and marketing \\
Advertising agency & Sole trader \\
Design services, consultation of management & Creative leader \\
\hline
\end{tabular}


Also, a group of young students were also interviewed, for their views on recruitment. Students expectation on the recruitment situation compared to what recruiters want in employees as well as the way they operate in the recruitment process. The students were universitylevel second-, third, and fourth-year IT students. Table 3 illustrates the comparison between the companies' and students' views, expectations and assumptions about what is expected and required from new employees, both from their skills and their personalities.

Table 3: Comparison between companies and students

\begin{tabular}{lll}
\hline $\begin{array}{l}\text { Desired characteristics / } \\
\text { skills }\end{array}$ & Companies' representatives & Students \\
\hline Attitude and world view & $\begin{array}{l}\text { Positive, enthusiastic attitude, willingness to learn new things, open- } \\
\text { ness toward change }\end{array}$ & Keenness, positivity, will for self-development \\
Personality & Standing out is an asset (especially in application stage) & $\begin{array}{l}\text { Personality was not mentioned in the interviews } \\
\text { by the students }\end{array}$ \\
Determinedness & $\begin{array}{l}\text { Desirable that applier knows what they want in the future and how } \\
\text { they want to develop themselves and that they justify their ideologies }\end{array}$ & tasks and how one wants to advance in work life \\
Interest towards business & Important, can be shown already in the application stage, for example & Important, can be shown by reading the compa- \\
area and company & by calling the company beforehand & ny's materials beforehand \\
Professional skills & Important, but attitude is even more important, skills are best shown & Very important, work experience plays an im- \\
portant part in showing one's professional skills & An important criterion \\
in practice, and willingness to learn new things is also important & Important, can be shown in the interview \\
Practical work in school & Important, teamwork and meeting with customers & Can be mentioned in CV. Practical parts difficulty \\
$\begin{array}{ll}\text { Own projects } \\
\text { Contact networks }\end{array}$ & Were stressed as an important sign of motivation and innovativeness & Was considered a good way to show one's skills \\
\hline
\end{tabular}

A significant finding on differences between the companies and the job-seekers answers was in the time span used to view things and to concretize actions. Companies were seeking new employers, with long term goals in mind. They want to recruit people who have the knowledge and skills to move forward in life and who are not afraid to express their personality and whose life attitude is that "by working, you can learn new things, and your skills grow on a daily basis". These people are popular employees because, according to research, their career goals can be easily supported by the organization [71]. On the other hand, the students' answers illustrate a short-term way of thinking e.g.: "I can take any work as my first workplace, as long as I find some work". Students did not see anything strange in this sort of thinking, it was "business as usual" for them. Basically, they had short term objective and goals which motivated them to act according, with certain behavioural model. Based on area specific research, if companies want to find those goal seeking applicants and to delve into the applicant's actual (life) aims, the entrepreneurs should create solutions for the applicants to do a self-assessment that could also tell more about their values, needs and objectives for the applicants themselves [72]. In applicant side, to improve the job seeking efficiency, According to Koena et al. [73] "... The use of a focused and exploratory strategy contributed to the number of job offers...".

Companies used interview to look for applicants who are determined and know wants they want in their life and why. As applicants, students viewed the manifestation of determinedness e.g. as a work task results point of view and not as much in regard of a life-long paths. For a company, to get into the bottom of applicant' long-term plans, a proper set the interview terminology and questions are needed. Moreover, candidate's awareness about desired for the job, correlated to higher willingness to be hired. Being aware of one's goals is useful for employers, as it is linked to expectation of motivated and inspired employee. Moreover, clearly identified employers' goals would make it easier for companies to support the future employee and make the company good career place for the employ ee. For the skills, the companies' viewed education as way to form a basis for professional skills and then the strong experience would be gained through years of hard work. This view meant for companies, that proper attitude would be a good basis for long term success. This made most companies to look for goal-oriented applicants. The students in turn thought that education (and course grades) form the professional skills (e.g. knowing how to code software properly) which the companies look for in their applicant's paperwork. To summarize, companies want to know what the employee wants. By understanding their needs, companies can offer them a work environment that enables the realization of their needs. Supporting their needs in turn creates positive motivation towards work, which can be observed directly in the amount and quality of results. In this way, supporting employees' orientation of clarified goals will increase employees' motivation towards work [23].

As for the procedures, a difference in thought was also observed in how keen people are / should be, to apply for work and how they show activity even before the actual job interview. The students' and employers' differences in opinion and views are mostly focused on the ways of showing interest for the business and employer. From students' perspective, one should learn more about the company and its business by reading material about the company and its field. From companies' view, showing one's interest should be concreate and visible to them. In other words, when in leaving an application, one can call the company, discuss about their wishes and needs, and revise the application according to the new information, as well as showing the new knowledge and learning in the cover letter of the application document. Companies are especially looking for determined employees, and they need people who are psychologically attached to their work [74]. As the attachment reasons to the work changes, as the society changes, companies should keep themselves familiar with different workforce generations workplace commitment reasons and the change directions of these commitment points [75].

\subsection{Visibility of company brands in recruitment}

When researching the chances of individual brands to support in building of company brands, a preparatory study was conducted on what currently companies' public brand images look like. While assessing the current situation of companies' brand visibility, it was noted that only some of the companies used social media actively in their marketing. Most companies that used social media, used them only for visibility and not notably for other purposes (such as honing their brand or company images). In this regard, the most popular channels of social media were Facebook, Twitter, Instagram and LinkedIn. In practice, the most popular ones seemed to be the most famous and also the ones with most users. On the other hand, through the interview process, no company mentioned that they had tried to examine what kinds of media their key customer groups usually use or if it would be, in their business and service, a good idea to be visible in some other social media or to use some other tools of social media to gain maximum effect.

There are many ways to aim at visibility, but funny posts and memes were typically mentioned, as they are popular. The companies did claim that they recognize the significance of brands. They mentioned that you will not get far with a bad brand nowadays, even if skills and quality are in order. The concrete experience-based view among the interviewees was that a better and more famous brand is just 
simply more successful. When companies were asked about what they thought about individual brands, practically every answer included the message that companies are not looking for any employee brands as such. Charisma and attitude are important factors in recruitment, and other significant and desired traits in employees include a positive, extroverted and enthusiastic attitude. In addition, activity and its visibility in everyday actions was also a highly valued characteristic. Employers told that you can show your activity even in the application stage with a perfected application and investing in the interview. In addition, as each new employee is a time, effort and resource related "future risk investment", which is made based on the information available, a recommendation from a trustworthy party significantly increases the chances of getting hired.

When comparing company brands to the company's employees' behaviour in social media, the following things were noted. A company with a strong brand in social media is stricter about how the employees behave in social media. In other words, these companies paid attention to factors that could affect their image directly and indirectly more widely and thoroughly than other companies. In the same vein, the companies using social media in their daily marketing mentioned that they appreciate employees who use social media in their leisure time. One company told that they usually do not even hire a person who does not use social media because their work requires understanding the structures and tools of social media in order to succeed. Also, for the companies', visual content plays a more important role than earlier, as visual applications are in average used more actively in social media. As for application and visuality, one company mentioned that they go through the applicant's Instagram account if one has been mentioned in the application. The same company also mentioned that they use the Snapchat application to share pictures as part of their marketing activities.

\subsection{Analysis and summary of the research data}

By analysing the research observations on visibility of company brands we ended up with following summary:

1) Companies' visual communication varies a lot, between the companies. And even within a company, depending on what they are promoting or communicating, the quality of presented message varies greatly, both qualitatively and quantitatively. Specially:

a) some companies have great amounts of diverse material available, while others have none

b) in many companies the quality of publicly available video material varied from professional quality to so-called amateur level

c) few companies had hired a specialized marketing professional but in most companies, job of informer was managed alongside other tasks or it was outsourced to third parties

2) There were companies that had barely any digital material, for example videos, available through the most used channels (e.g. Vimeo \& YouTube), which can nowadays raise questions about the future plans of the company. E.g. do they take their business seriously specially if they say that they are open minded etc.

3) The use of communication resources did not seem be as well planned as what the situation was with development, services, sales, maintenance or in other management processes in their business activities

4) When discussing the topic with parties who are responsible for certain tasks related to communication or who work with external interfaces, we found surprising explanations why the situation is what it is:

a) Some companies had deliberately chosen to take an invisible model of visibility. Current sales work already generates too much work, so they don't have resources to respond to any additional amount of work caused by better visual marketing or brand promotion work

b) Companies had both old and new material available in their communication channels. In general, it is important to clean the old material away, but this form of work was not given as task to anyone in the company (there is room for improvement in making the roles of communication clearer).

c) When a companies' consumers come from different fields and as the company's product design follows the current trends, the newest communication followed the trend, but they did not clean up the old material away, so the message that presented the company's current activities in mixed way.

d) The great qualitative variation of a company's material was recognized as a challenge, and it was also agreed that it should also be made clear at least to the recipient why the material is completely different from what seems to be the "normal" level of professional communication in the company. How this will be solved in future, was still not clear at this point.

Based on the observations made from the research literature, the general trend is as follows. If a company want to support the spreading of their brand and to alleviate the spreading of the brand material, they should support their works in this process. Accordingly, the companies should support networking and maintaining networks because that is what people want to do e.g. in social media [76-79]. This means that companies should stay up-to-date and follow what is important for people in social media at a certain time and place and offer brand communication that supports the realization of these things that are considered important. This means that a brand message should be conveyed so that the things that people consider important are realized primarily, and that the conveying of the brand message itself can be conveyed by people with their own volition. How this is realized on a case-by-case basis depends on the context where the communication happens, but it is possible to look for inspiration by, for instance, reading about the guerrilla marketing ideology (e.g. Cova \& Saucet [80]). In addition, SMEs should especially include procedures different from big companies' policies in their marketing communication in order to differentiate themselves from big brands and to increase their influence by approaching the marketing challenge, for example through 'entrepreneurial sensemaking' [81].

\section{Discussion and interpretation of the results}

From marketing and brand visibility perspective, companies' current video material and state of their visual visibility was not in the level we would have expected, compared to their views to digitalization and social media branding. In other words, there is still remarkable gap for improving companies' brand communication e.g. in social media as well as digital material. On another hand, the weak visibility in visual and digital marketing material is not necessarily a sign of mismanagement, and it might be a deliberate choice as some of the interviewed companies explained the situation. In other words, if one wants to know what in reality companies are capable of doing and what kinds of results they have achieved, it is a good idea to ask for references and recommendations instead of focusing the attention on what and how the company shows their work publicly. To summarize, it could be said that the actual results found through the company's peers weigh more than sleek appearances. As in similar way with recruitment the final decision should be based on the actual will to learn and work, not with numbers on a paper. In addition, the new generation of brand communication solutions are yet to reach the de facto position in SME sized corporate front, which might well explain why SME's do not have as strong presence e.g. in social media, even though social media platforms in general, are easily adopted to use, by the small companies. 
However, for SMEs the cost efficiency of social media is apparent with large audience communication. With the right use, social media can also be used "automatically" as a skill portfolio tool besides informing, communication, and involvement [42]. One downside of the social media is that it gives these advantages for everyone. In this regard, the result could be that the market will be divided to a larger group of small companies, for which the end results will be smaller share for everyone. Related on pros and cons of social media as a support tool for entrepreneurship [42] explain the situation from female point of view as follows in Table 4.

Table 4: The Pros and Cons of Social Media (Based on Genç and Öksüz [42])

\begin{tabular}{ll}
\hline Positives & Challenges \\
\hline Affordable sharing of information & Undefined target audience \\
Constant communication & Unfair competition \\
Large-scale networking & Decreased market share \\
Easy to follow trends & Copying products and services \\
Presenting one's portfolio & \\
\hline
\end{tabular}

As a general observation of the differences in notions and thoughts, the research found that companies often claimed that they are not looking for people who brand themselves, but also almost immediately specified in interviews that they want to find good employee personalities who stand out. They look for active applicants, which is shown by the persons common ways of doing things and many times also a part of their quite static personality components. Considering the ways young applicants could show this activity, for further research, it could be examined e.g. how many applicants actually call or other ways contact the company. Activity can be practically shown by finding out what kind of an employee company truly looks for and why.

As a summary, companies look for employees with individual brands in line with the company values and image. Companies want to recruit people with employer suiting branding. Hence, the fundamental idea is the same, but the terminology and the way of perceiving the objectives are different in pragmatic sense, even with similar interpretations. Considering the findings and summary conclusion, one should take a note about the limitations of this study. First of all, the sample size; a limited number (less than 50) small and medium sized enterprises were studied. Secondly, the data was collected from geographically limited area (namely inside Finland). The research does illustrate the situation of growing SMEs and similar companies well, but it should not be generalized to all company types or sizes. As for the applicants interviewed and surveyed, the research focused mostly young millennials and older Generation $\mathrm{Z}$ students and little to no data was collected from the age group of 30 years and above.

\section{Practical implications}

As for companies' value training, the orientation of new employees should strongly include models, where parties who are not yet familiar with the company familiarize with the company's external brand and write a report about this familiarization by documenting the emotions related to the presentation of the external brand. Since a new employee is not yet fully aware of the company's internal structures and is completely dependent on the external material like any third party, they have the possibility to observe nuances that the internal personnel of the company are not able to notice anymore. These observations are essential insights for companies to aligning seamless outwards-oriented brand image and the actual internal operation together with each other. When a person who has analysed the external communication enters the company and is surprised when the company's internal structures conflict with the external brand image, it is fairly likely that, for instance, potential customers (especially in the B2B sector) will experience the same feeling too. The experience of conflict paints a questionable picture about company's professionalism. From the other point of view, as the company is also just starting to get to know the new employee trough the time he/she is working in company, the organisation should try to understand the dreams and life goals of the person, and consider the options, could they boost these goals with helping the person build their social media brand too, in this symbiotic relationship. If the company can help the person to achieve their goals and understand are they doing all they can, or the right things [82], to achieve their dreams, it is assumed that the person will do the same for the company too.

As operations ger more complicated, the conflicting communication can increase too. Difficult topics and some even problems will be covered with evasive talks and explanations, which easily lead to a circle of defensive routines. In the current digital era, people tend to notice this and see through the false communication, so it is best not to get involved in this kind of a path. Because vagueness in communication suggests that the communicators themselves do not know what they are really talking about, and this in turn does not inspire confidence towards capabilities of the company [83]. In short, it is a good idea to embrace all channels and opportunities that can develop the company's external communication through the experiences of an external brand's visibility and a new employee's brand skills.

\subsection{Advice and instructions from literature for using social media in companies}

Based on the aforementioned research interviews, summarized research data, and analysis, academic literature views could be compared to out observations, for more efficient presence in social media. This will then help companies to build brand name so that it supports the company's marketing and desired communicational image. Even though it could be claimed that for a brand, positive activities in social media are completely identical in successful markets, it is not similar. Social media is about participation, sharing, discussion and cooperation, and not straightforward trade or advertisement. By choosing wisely which social media channels you shall be active in, you can start developing your brand image 'resource-efficiently'. As you cannot be active in channels all the time, it is important to choose the most efficient and effective channels in your own business sector. That way, you should find the time and required skills to reach the desired target audiences. In many cases, the best solution is to directly participate in the user level discussions in social media, in those media channels where the users are anyways naturally sharing their ideas and sources of inspiration. Bring some new and added value into those conversations, and you should get some positive visibility. It is also valuable to study your target audience, and try to understand why they participate, specially freely, to certain activities and what makes them to be motivated to contribute their time to different platforms [84]. The most efficient solution is probably to combine marketing in social media and traditional marketing because, from customers' point of view, they both are a part of a company's image. In best cases, customers can even give food advices on how to get their undivided attention better in next try [85]. The interviewees on our study had internalized the general spirit of those tips, but literature was still a step ahead of these companies, when you look into the deepness of implementing these ideas. According to Kaplan and Haenlein [85], efficient procedures in social media can be achieved as follows:

- choose your social media channels wisely

- choose your social media services according to your target group 
- be active where your customers are active, participate and share contents actively

- create interesting contents, consider what the customers really want to hear

- be humble, start by familiarizing the structure of the service and its existing communication culture

- arrange consistent communication in different channels, remove conflicting communication or information

- combine your traditional marketing with social media marketing

- $\quad$ create social media guidelines and ensure that your employees are active in selected medias

- do not be afraid of making mistakes and do not be too professional $\rightarrow$ blend in in a down-to-earth way

- $\quad$ listen to your customers and act on / respond into their needs

- be honest and respect the rules of social media (channel)

Paradiso [14] suggests companies to encourage their employees to commit company's social media strategy. Paradiso also recommends hiring a social media guru, which in practice is a person who handles the communication in social media actively. This professional of communication would familiarize with the company's culture and ensure that they understand what is expected for them and what the company wants to express through social media [86]. Furthermore, Feedback is important in the orientation of new employees. In addition, Paradiso [14] recommends that companies should follow their web analytics. You should not be afraid of mistakes, but you should learn from them. The right attitude towards real life is that "failure is a chance to grow and change". As the social media is changing rapidly on a daily basis, you should be prepared to learn new skills, follow people's communication models, and try out new tools [14].

\subsection{The meaning of individual brands for company brands}

Besides considering employees' social behaviour, the company's own communication, and the chosen brand name is important. Currently, people with their own personal brand (celebrities) have been added into companies' marketing "toolkit" for creating a better-known company brand. Celebrities can bring the desired additional visibility to a brand as well as creating desired associations about different values and lifestyles [87]. This could be interpreted as significant evidence about how individual brands can affect company brands and the possible ways modern marketing can differentiate itself from old ways. In fact, companies should pay more attention to individual brands in their operations and recruitment in the future. Especially when external communication and employee experience with the company brand positively affect the brand commitment of employees, in the light of recent studies [88].

In addition, based on the topics mentioned by the interviewed companies and students, young applicants do not seem to pay enough attention to the significance of their own personality and how they communicate it as a means to get the job. Additional research culd be utilized to study how much possibly poorly presented personality affects the good workers ability to be hired nowadays. Considering a virtual individual brand in practice, an applicant can stand out with, for example, a distinctive website portfolio. It is easy to make a website look unique, but the challenging part is to create a website that reflects one's true personality. For companies, it is especially difficult if they are looking for good employees, but also for people with good individual brands to spread the company brand in networks used by individuals, if we are dealing with the situation, where either skills and/or resources are not clearly visible in the application phase.

\section{Conclusion and summary}

In the light of the literature and researched companies' current state, SMEs have a lot to improve in digitalization, social media, and the expression of brands that are present in digital channels. They have room for improvement both in honing their existing brand images and adopting the potential of individual brand images. In addition, there is a clear need to create procedures and processes and to support the boosting of individual brand images. This research surveyed the current state of this phenomenon in the context of Finnish SMEs by reflecting concrete research data to the guidelines and strategies mentioned by research literature on how coordinating the information deliveries to customers and applicants can create added value for the business owners. In this sort of follow up research, organizations have change to learn a lot form their past decisions in marketing strategy, if the brand image is seen differently as the company management has intended. For example, using Actor network-theory (ANT) to explore the social to answer "how" questions about structure, power and organizations [89] and to connect it to newest related research in actor-network theory on marketing and consumption context [90]. Also, considering the general ideology of improving company brand, in collaboration with the employers social media brand, we would recommend SME companies to collaborate more with universities [91], as the university students are generally speaking quite close in their life to enter to job markets and also typically quite young and well connected to social media platforms, so this sort of collaboration should naturally bring companies closer to the source of possible new future recruits, who could help them to build their brand. The core findings of the research are listed in Table 5 below.

Table 5: Summarized Research Results, Empirical Doctrines, and Conclusions

\begin{tabular}{|c|c|c|}
\hline Observation type & Observation source & Doctrines \\
\hline Challenges and misunderstandings & & \\
\hline $\begin{array}{l}\text { Companies skills and brand outlook from employ- } \\
\text { ees, but they do not offer enough support for these. } \\
\text { This sends contradictory signals for employees. Re- } \\
\text { quiring e.g. some output, but the organization does } \\
\text { not give support for it. This evokes confusion } \\
\text { among the employees about whether something is } \\
\text { really wanted or not. } \\
\text { It is difficult for SMEs to gather their entire staff } \\
\text { simultaneously to one place as their resources are } \\
\text { constantly bound to running their daily operation. } \\
\text { Companies want that their brand information is } \\
\text { spread widely, but there are hardly any norms on } \\
\text { how not to mix civil and work life together in social } \\
\text { media to not to connect the company to non-wanted } \\
\text { contexts. }\end{array}$ & $\begin{array}{l}\text { Interviews } \\
\text { and literature. }\end{array}$ & $\begin{array}{l}\text { Clear strategies and objectives from the company so that it } \\
\text { easier to express them to new employees in the recruitment } \\
\text { process as well. More information about why certain things } \\
\text { are requested. } \\
\text { Limited resources demand substantial creativity of SMEs, } \\
\text { one creative way to approach this challenge is to divide the } \\
\text { time of presence to smaller pieces and to conduct a part of } \\
\text { mutual learning in a virtual work environment by using } \\
\text { asynchronous work methods } \\
\text { Guidelines of behaviour in social media for employees } \\
\text { while also maintaining the individual right not to publish } \\
\text { the company's advertisements. It is a good idea to help the } \\
\text { employees to create their own social media profiles and } \\
\text { help them to get started with communication. By doing this, } \\
\text { employees can learn ways of utilizing these platforms in } \\
\text { their leisure time, making the utilization also easier at work. }\end{array}$ \\
\hline
\end{tabular}




\begin{tabular}{|c|c|c|c|}
\hline \multicolumn{4}{|c|}{ Advantages } \\
\hline$\bullet$ & Advantages in companies' visibility & $\begin{array}{ll}\text { - Interviews \& } \\
\text { literature }\end{array}$ & $\begin{array}{l}\text { Affordable and fast spreading of information (does acquire } \\
\text { constant presence). }\end{array}$ \\
\hline$\bullet$ & Advantages in creating individual brands & $\begin{array}{l}\text { Interviews \& } \\
\text { literature }\end{array}$ & $\begin{array}{l}\text { Possibility to reach the awareness of parties that would oth- } \\
\text { erwise be difficult to reach. }\end{array}$ \\
\hline$\bullet$ & Work orientation & $\begin{array}{l}\text { Interviews \& } \\
\text { literature } \\
\text { Interviews }\end{array}$ & $\begin{array}{l}\text { - The company's brand is visible in social media. Opportuni- } \\
\text { ty to compare external and internal visibility because the }\end{array}$ \\
\hline
\end{tabular}

The summary demonstrated how companies have various wishes, but how they also have forgot to build and provide facilities that could be used to help and support the realization of these wishes. What has also happened is that from an employee's point of view, it seems like the company sets requirements, but does not stand behind these wishes while also cramming the pressure of operative productivity on the employees. When this happens, the employee will quickly start working for the apparently desired operative results and think that they are doing what the company wants from them. As a result, the management is disappointed in the employees because some of the basic work-related requirements get forgotten so it might seem like the employees are not interested in committing themselves to the development goals set by the company heads. Also, too much cumulative pressure, has different effects to productivity, with people in general [92], meaning the management needs to know, what sort of personality and group culture they work with, before pushing too hard. As for further research, we suggest an empiric field research of this conflicting situation, examining the root causes of this phenomenon. Within the companies, there is a need to create research-based, proven and concrete solution to decrease the simmering bad mood in the work environment and bring more meaning for the everyday work.

\section{Acknowledgement}

Authors thank the European Regional Development Funds and Regional Council of South Karelia for funding MINT project, allowing to collect the data and finalize the analysis on this SME supporting research. We also to express our gratitude for South-East Finland - Russia CBC programme for supporting AWARE project, funded by the European Union, the Russian Federation and the Republic of Finland. The funding and project made it possible for publishing this work and to be able to disseminate the knowledge about possibilities of SME to make their sustainability related efforts more widely known by general public trough individual social media brands.

\section{References}

[1] Bolhuis, W., de Jong, M.D.T., van den Bosch, A.L.M. (2018), Corporate rebranding: effects of corporate visual identity changes on employees and consumers, Journal of Marketing Communications, Vol. 24, No. 1, pp. 3-16, https://doi.org/10.1080/13527266.2015.1067244.

[2] Williamson, I.O., King Jr., J.E., Lepak, D., Sarma, A. (2010), Firm Reputation, Recruitment, Websites and Attracting Applicants. Human Resource Management, Vol. 49, No. 4, 669-687, https://doi.org/10.1002/hrm.20379.

[3] Appel, G., Grewal, L., Hadi, R., Stephen, A.T. (2020), The future of social media in marketing, Journal of the Academy of Marketing Science, Vol. 48, pp. 79-95, https://doi.org/10.1007/s11747-019-00695-1.

[4] Kaita-aho, J., 2016. Somessa maine pitää ansaita - Yritykselle viidakkorumpu on uhka. Yle Uutiset.. [Online] Available at: https://yle.fi/uutiset/38890511 [Accessed 05-12-2021].

[5] Piili, H., Widmaier, T., Happonen, A., Juhanko, J., Salminen, A., Kuosmanen, P., Nyrhilä, O. (2013), Digital design process and additive manufacturing of a configurable product, Advanced Science Letters, Vol. 19, No. 3, pp. 926-931, https://doi.org/10.1166/asl.2013.4827.

[6] Widmaier, T., Juhanko, J., Piili, H., Kuosmanen, P., Salminen, A., Happonen, A., Kontio, J., Nyrhilä, O. (2013), Digital design and manufacturing process comparison for new custom made product family - a case study of a bathroom faucet, Estonian Journal of Engineering, Vol. 19, No. 1, pp. 76-89, https://doi.org/10.3176/eng.2013.1.07.

[7] Kortelainen, H., Happonen, A., Hanski, J. (2019), From Asset Provider to Knowledge Company-Transformation in the Digital Era, In Lecture Notes in Mechanical Engineering, pp. 333-341, https://doi.org/10.1007/978-3-319-95711-1 33.

[8] Minashkina, D., Happonen, A. (2020), Decarbonizing warehousing activities through digitalization and automatization with WMS integration for sustainability supporting operations, E3S Web of Conferences, Vol. 158, article: 03002, pp. 1-7, https://doi.org/10.1051/e3sconf/202015803002

[9] Geurin, A. N. (2013), Acceptance, motivations, and usage of social media as a marketing communications tool amongst employees of sport national governing bodies. Sport Management Review, Vol. 16, Iss. 4, pp. 488-497 https://doi.org/10.1016/j.smr.2013.03.004.

[10] Salmela, E., Happonen, A. (2012), Applying Social Media in Collaborative Brainstorming and Creation of Common Understanding Between Independent Organizations, In Knowledge Management / Book 2: New Research on Knowledge Management Applications and Lesson Learned, pp. 195-212, https://doi.org/10.5772/2529.

[11] Dahnil, M., Mizal Marzuki, K., Langgat, J. \& Fabeil, N. F. (2014), Factors Influencing SMEs Adoption of Social Media Marketing. Social and Behavioral Sciences, Vol. 148, Iss. 1, pp. 119-126, https://doi.org/10.1016/j.sbspro.2014.07.025.

[12] Mohajerani, A., Baptista, J., Nandhakumar, J. (2015), Exploring the role of social media in importing logics across social contexts: The case of IT SMEs in Iran, Technological Forecasting and Social Change, Vol. 95, pp. 16-31, https://doi.org/10.1016/j.techfore.2014.06.008.

[13] Paniagua, J., Bolufer, J.S. (2014), Business performance and social media: Love or hate?. Business Horizons , Vol. 57, Iss. 6, pp. 719-728, https://doi.org/10.1016/j.bushor.2014.07.005

[14] Paradiso, C. (2016), Digital Marketing: Commitment Drives Success, Rough Notes, Vol. 159, Iss. 5, pp. 33-35

[15] Meske, C., Stieglitz, S. (2013), Adoption and Use of Social Media in Small and Medium-Sized Enterprises. s.l., Practice-Driven Research on Enterprise Transformation. https://doi.org/10.1007/978-3-642-38774-6_5.

[16] Stockdale, R., Standing, C. (2006), An interpretive approach to evaluating information systems: A content, context, process framework, European Journal of Operational Research, Vol. 173, Iss. 3, pp. 1090-1102, https://doi.org/10.1016/j.ejor.2005.07.006.

[17] BSR Stars (2013) Report: Knowledge Sharing Tools and Practices. Baltic Sea Region.

[18] Gilmore, A., Gallagher, D., Scott, H. (2007), E-marketing and SMEs: Operational lessons for the future, European Business Review, Vol. 19, No. 3. pp. 234-247, https://doi.org/10.1108/09555340710746482.

[19] Treem, J. W., Leonardi, M.P. (2012), Social Media Use in Organizations: Exploring the Affordances of Visibility, Editability, Persistence, and Association, Communication Yearbook, SSRN Electronic Journal, Vol. 36, pp. 143-189 https://doi.org/10.1080/23808985.2013.11679130.

[20] Wickramasinghe, D., Wickramasinghe, V. (2012), Effects of perceived organisational support on participation in decision making, affective commitment and job satisfaction in lean production in Sri Lanka, Journal of Manufacturing Technology Management, Vol. 23, Iss. 2, pp. 157-177, https://doi.org/10.1108/17410381211202179.

[21] Day, R., Allen, T.D. (2004), the relationship between career motivation and self-efficacy with protégé career success, Journal of Vocational Behavior, Vol. 64, Iss. 1, pp. 72-91, https://doi.org/10.1016/S0001-8791(03)00036-8. 
[22] Happonen, A., Siljander, V. (2020), Gainsharing in logistics outsourcing: trust leads to success in the digital era, International Journal of Collaborative Enterprise, Vol. 6, No. 2, pp. 150-175, https://doi.org/10.1504/IJCENT.2020.110221.

[23] King, C., Grace, D. (2012), Examining the antecedents of positive employee brand-related attitudes and behaviours, European Journal of Marketing, Vol. 46, No. 3/4, pp. 469-488, https://doi.org/10.1108/03090561211202567.

[24] Vatousios, A., Happonen, A. (2021), Renewed Talent Management: More Productive Development Teams with Digitalization Supported HR Tools, International journal of engineering \& technology, Vol. 10, No. 2, Article: 31705, pp. 170-180, https://doi.org/10.14419/ijet.v10i2.31705.

[25] Vatousios, A., Happonen, A. (2022), Transforming HR and Improving Talent Profiling with Qualitative Analysis Digitalization on Candidates for Career and Team Development Efforts, In book: Intelligent Computing, Lecture Notes in Networks and Systems, Vol. 283, Chapter 78, Springer, pp. 1149-1166, https://doi.org/10.1007/978-3-030-80119-9 78.

[26] Antin, J., Churchill, E.F. (2011), Badges in Social Media: A Social Psychological Perspective. s.l., ACM CHI Conference on Human Factors in Computing Systems, CHI 2011, May 7-12, 2011, Vancouver, BC, Canada.

[27] Nicholson, S. (2015), A RECIPE for Meaningful Gamification, In: Gamification in Education and Business, Springer, pp. 1-20, https://doi.org/10.1007/978-3-319-10208-5_1.

[28] Lyone, P., Bandura, R.P. (2016), Learning to identify employees that are engaged, helpful and proactive, Industrial and Commercial Training, Vol. 48, No. 3, pp. 163-169, https://doi.org/10.1108/ICT-09-2015-0065.

[29] Govaerts, N., Kyndt, E., Dochy, F., Baert, H. (2011), Influence of learning and working climate on the retention of talented employees, Journal of Workplace Learning, Vol. 23, Iss. 1, pp. 35-55, https://doi.org/10.1108/13665621111097245.

[30] Locke, E.A., Latham, G.P., Smith, K.J., Wood, R.E., Bandura, A. (1990), A Theory of Goal Setting \& Task Performance, Pearson College Div, ISBN-13: 978-0139131387, p. 413

[31] Stein, M., Christiansen, L. (2010), Successful Onboarding: Strategies to Unlock Hidden Value Within Your Organization, McGraw Hill Professional, ISBN-13: 978-0071739375, p. 288

[32] Lin, E., 2014. Pluralism about Well-Being. Philosophical perspectives, Vol. 28, Iss. 1, pp. 127-154, https://doi.org/10.1111/phpe.12038.

[33] Smith, A., Stirling, A., Berkhout, F. (2005), The governance of sustainable socio-technical transitions, Research Policy, Vol. 34, Iss. 10, pp. 14911510, https://doi.org/10.1016/j.respol.2005.07.005.

[34] Mitchell, R., Hutchinson, K., Quinn, B., Gilmore, A. (2015), A framework for SME retail branding. Journal of Marketing Management, Vol. 31, Iss. 17-18, pp. 1818-1850, https://doi.org/10.1080/0267257X.2015.1063531.

[35] Hess, J.S., Singh, J., Metcalf, L.E., Danes, J. (2014), The Impact of Consumer Product Package Quality on Consumption Satisfaction, Brand Perceptions, Consumer Investment and Behavior. Journal of Applied Packaging Research, Vol. 6, Iss. 1, pp. 23-39, https://doi.org/10.14448/japr.01.0003.

[36] Happonen, A., Ghoreishi, M. (2022), A mapping study of the current literature on digitalization and industry 4.0 technologies utilization for sustainability and circular economy in textile industries, Lecture Notes in Networks and Systems, Vol. 217, Chapter 63, pp. 697-711, https://doi.org/10.1007/978-981-16-2102-4_63.

[37] Ghoreishi, M., Happonen, A. (2020), Key enablers for deploying artificial intelligence for circular economy embracing sustainable product design: Three case studies, AIP Conference Proceedings, Vol. 2233, Iss. 1, p. 1-19, https://doi.org/10.1063/5.0001339.

[38] Taipale, J., 2007. Brändi liiketoiminnan ytimessä - erotu tai unohda koko homma, Helsinki: Infor Oy.

[39] Wong, A., Yazdanifard, R. (2015), The Review of Content Marketing as a New Trend in Marketing Practices, International Journal of Management, Accounting and Economics, Vol. 2, No. 9, pp. 1055-1064

[40] Tolvanen, V. (2013), Brändi, blog post, Available at: http://www.villetolvanen.com/fi/2013/10/03/brandi/

[41] Deszczyński, B., Luczak, M, Wieczerzycki, M. (2017), Social media as a tool to support building relationships in the international market, In book: Changes and Challenges in the Modern World Economy. Recent Advances in Research on International Economics \& Business, Publisher: Wydawnictwo Uniwersytetu Ekonomicznego, pp. 349-369

[42] Genç, M., Öksüz, B. (2015), A Fact or an Illusion: Effective Social Media usage of Female Entrepreneurs. Social and Behavioral Sciences, Vol. 195, pp. 293-300, https://doi.org/10.1016/j.sbspro.2015.06.345.

[43] Arora, S., Karlo, A., Sharma, D. (2015), A comprehensive framework of brand name classification. Journal of Brand Management, Vo. 22, Iss. 2, pp. 79-116, https://doi.org/10.1057/bm.2015.8.

[44] Wongpreedee, K., Kiratisin, A., Virutamasen, P. (2015), Entrepreneurial Mindsets for Innovative Brand Development: Case Studies in Jewellery Education. Procedia - Social and Behavioral Sciences, Vol. 195, pp. 2236-2241, https://doi.org/10.1016/j.sbspro.2015.06.308.

[45] Frey, C., Ansar, A., Wunsch-Vincent, S. (2015), Defining and Measuring the "Market for Brands": Are Emerging Economies Catching up?. The Journal of World Intellectual Property, Vol. 18, Iss. 5, pp. 217-244. https://doi.org/10.1111/jwip.12041.

[46] Sarkar, A.N., Singh, J. (2005), New Paradigm in Evolving Brand Management Strategy, Journal of Management Research, Vol. 5, No. 2, p. 80-90

[47] Barney, J. (1986), Organizational culture: Can it be a source of sustained competetive advantage?, Academic Management Review, Vol. 11, Iss. 3, pp. 656-665. https://doi.org/10.5465/amr.1986.4306261.

[48] Schein, E. (1990), Organizational Culture. American Psychologist, Vol. 45, Iss. 2, pp. 109-119, https://doi.org/10.1037/0003-066X.45.2.109.

[49] Hofstede, G., Neuijen, B., Ohvay, D. \& Sanders, G. (1990), Measuring Organizational Cultures: A Qualitative and Quantitative Study Across Twenty Cases. Administrative Science Quarterly, Vol. 35, No. 2, pp. 286-316, https://doi.org/10.2307/2393392.

[50] Lemon, M., Sahota, P.S. (2004), Organizational culture as a knowledge repository for increased innovative capacity. Technovation, Vol. 24, Iss. 6, pp. 483-498, https://doi.org/10.1016/S0166-4972(02)00102-5.

[51] Smircich, L., 1983. The concepts of organization culture and organizational analysis. Administrative Science Quarterly, Vol. 2, Iss. 3, pp. 339-358. https://doi.org/10.2307/2392246.

[52] Fang, T. (2011), Ying Yang: A new Perspective on Culture. Management and Organization Review, Vol. 8, Iss. 1, pp. 25-50, https://doi.org/10.1111/j.1740-8784.2011.00221.x.

[53] Santti, U., Eskelinen, T., Rajahonka, M., Villman, R., Happonen, A. (2017), Effects of Business Model Development Projects on Organizational Culture: A Multiple Case Study of SMEs, TIM, Vol. 7, Iss. 8, pp. 15-26, https://doi.org/10.22215/timreview/1096.

[54] Cameron, K., Quinn, R. (2006), Diagnosing and Changing Organizational CUlture: Based on Competing Values Framework. Revised Edition toim. s.1.:Jossey-Bass.

[55] Denison, D.R., Spreitzer, G.M. (1991), Organizational culture and organizational development: A competing values approach. Research in Organizational Change and Development, Vol. 5, pp. 1-21.

[56] Yu, T., Wu, N. (2009), A review of study on the competing values framework, International Journal of Business and Management, Vol. 4, Iss. 7, pp. 1-37, https://doi.org/10.5539/ijbm.v4n7p37.

[57] Cameron, K. (2009), An introduction to the competing values framework. Organizational culture white paper.

[58] Helms Mills, J., Thurlow, A., Mills, A.J. (2010), Making sense of sensemaking: the critical sensemaking approach, Qualitative Research in Organizations and Management, Vol. 5, No. 2, pp. 182-195, https://doi.org/10.1108/17465641011068857.

[59] Weick, K.E., Sutcliffe, K.M., Obstfeld, D. (2005), Organizing and the process of sensemaking. Organization science, Vol. 16, Iss. 4, pp. 409-421, https://doi.org/10.1287/orsc.1050.0133.

[60] Long, B.S., Helms Mills, J. (2010), Workplace spirituality, contested meaning, and the culture of organization: a critical sensemaking account, Journal of Organizational Change Management, Vol. 23, Iss. 3, pp. 325-341, https://doi.org/10.1108/09534811011049635.

[61] Mills, J.H., Thurlow, A., Mills, A. (2010), Making sense of sensemaking: the critical sensemaking approach, Qualitative Research in Organizations and Management, Vol. 5, No. 2, pp. 182-195, https://doi.org/10.1108/17465641011068857.

[62] Lavine, M. (2014), Paradoxical leadership and the competing values framework, The Journal of Applied Behavioral Science, Vol. 50, Iss. 2, pp. 189-205, https://doi.org/10.1177/0021886314522510. 
[63] Hatch, M.J., Schultz, M. (2002), The Dynamics of Organizational Identity, Human Relations, Vol. 55, Iss. 8, pp. 989-1018, https://doi.org/10.1177/0018726702055008181.

[64] Aaltio, 1., Salminen, H., Koponen, S. (2014), Agening employees and human resource management - evidence of gender sensitivity, equality, diversity and inclusion. An International Journal, Vol. 33, No. 2, pp. 160-176, https://doi.org/10.1108/EDI-10-2011-0076.

[65] Snape, E., Redman, T. (2003), Too old or too young? The impact of perceived age discrimination, Human Resource Management Journal, Vol. 13, Iss. 1, pp. 78-89, https://doi.org/10.1111/j.1748-8583.2003.tb00085.x.

[66] Fabien, L. (1997), Making promises: the power of engagement, Journal of Services Marketing, Vol. 11, No. 3, pp. 206-214, https://doi.org/10.1108/08876049710168690.

[67] Albert, S., Ashforth, B.E., Dutton, J. (2000), Organizational identity and identification: Charting new waters and building new bridges. Academy of management Review, Vol. 25, No. 1, pp. 13-17 https://doi.org/10.5465/amr.2000.2791600

[68] Puusa, A., Tolvanen, U. (2006), Organizational identity and trust. EJBO-Electronic Journal of Business Ethics and Organization Studies, Vol. 11, No. 2, pp. 29-33

[69] Gioia, D.A., Achultz, M., Corely, K.G. (2000), Organizational identity, image, and adaptive instability. Academy of management review, Vol. 25, No. 1, pp. 63-81, https://doi.org/10.2307/259263.

[70] Ravasi, D., Schultz, M. (2006), Responding to organizational identity threats: Exploring the role of organizational culture. Academy of management journal, Vol. 49, No. 3, pp. 433-458, https://doi.org/10.2307/20159775.

[71] Takeuchi, Y.J.N. (2016), Gender differences in career planning and success, Journal of Managerial Psychology, Vol. 31, Iss. 2, p. 603-623, https://doi.org/10.1108/JMP-09-2014-0281.

[72] Jianguo, L., Maoyan, H. (2012), Exploratory Analysis of the Substance of Work Security in Harmonious Society. In: Wu Y. (eds) Advanced Technology in Teaching - Proceedings of the 2009 3rd International Conference on Teaching and Computational Science (WTCS 2009), Advances in Intelligent and Soft Computing, Vol. 116, pp. 367-372, https://doi.org/10.1007/978-3-642-11276-8_47.

[73] Koen, J., Klehe, U-C., Van Vianen, A.E.M., Zikic, J., Nauta, A. (2010), Job-search strategies and reemployment quality: The impact of career adaptability, Journal of Vocational Behavior, Vol. 77, Iss. 1, pp. 126-139, https://doi.org/10.1016/j.jvb.2010.02.004.

[74] Bakker, A.B., Albrecht, S.L., Leiter, M.P. (2011), Key questions regarding work engagement, European Journal of Work and Organizational Psychology, Vol. 20, Iss. 1, pp. 4-28, https://doi.org/10.1080/1359432X.2010.485352.

[75] van Rossenberg, Y.G.T., Klein, H.J., Asplund, K., Bentein, K., Breitsohl, H., Cohen, A., Cross, D., de Aguiar Rodrigues, A.C., Duflot, V., Kilroy, S., Ali, N., Rapti, A., Ruhle, S., Solinger, O., Swart, J., Yalabik, Z.Y. (2018), The future of workplace commitment: key questions and directions, European Journal of Work and Organizational Psychology, Vol. 27, Iss. 2, pp. 153-167, https://doi.org/10.1080/1359432X.2018.1443914

[76] Bonds-Raacke, J., Raacke, J. (2010), MySpace and Facebook: Identifying Dimensions of Uses and Gratifications for Friend Networking Sites, Individual Differences Research, Vol. 8, No. 1, pp. 27-33

[77] Chen, Y., Fay, S., Wang, Q. (2011), The Role of Marketing in Social Media: How Online Consumer Reviews Evolve, Journal of Interactive Marketing, Vol. 25, Iss. 2, pp. 1-32, https://doi.org/10.2139/ssrn.1710357.

[78] Li, Y., Lin, G. (2012). Results of a survey of Hong Kong University. China Media Research, Vol. 8, Iss. 1, pp. 54-63

[79] Kim, J.H., Kim, M., Nam, Y. (2010). An analysis of self-construals, motivations, Facebook use, and user satisfaction. International Journal of Human-Computer Interaction, Vol 26, Iss. 11-12, pp. 1077-1099 https://doi.org/10.1080/10447318.2010.516726.

[80] Cova, B., Saucet, M. (2014), Unconventional marketing: From guerrilla to consumer made, The Routledge companion to the future of marketing, pp. 252-268 https://doi.org/10.4324/9780203103036-24.

[81] Bettiol, M., Di Maria, E., Finotto, V. (2012), Marketing in SMEs: the role of entrepreneurial sensemaking, International Entrepreneurship and Management Journal, Vol. 8, pp. 223-248, https://doi.org/10.1007/s11365-011-0174-3.

[82] Salmela, E., Happonen, A. (2021), Are You doing the Right Things? Initial Stages of Individuals Change Management: Identify, Acknowledge and Make a Courageous Move Framework, In Book: Selected Topics in Humanities and Social Sciences, Vol. 2, pp. 12-25, https://doi.org/10.9734/bpi/sthss/v2/9389D.

[83] Argyris, C. (2004), Double-Loop Learning and Implementable Validity, In: Tsoukas H., Mylonopoulos N. (eds) Organizations as Knowledge Systems. Palgrave Macmillan, London, pp 29-45, https://doi.org/10.1057/9780230524545 2.

[84] Palacin, V., Gilbert, S., Orchard, S., Eaton, A., Ferrario, M.A., Happonen, A. (2020). Drivers of Participation in Digital Citizen Science: Case Studies on Järviwiki and Safecast, Citizen Science: Theory and Practice, Vol. 5, Iss. 1, Article: 22, pp. 1-20, https://doi.org/10.5334/cstp.290.

[85] Kaplan, A., Haenlein, M. (2010), Users of the world, unite! The challenges and opportunities of Social Media, Business Horizons, Vol. 53, Iss. 1, pp. 59-68, https://doi.org/10.1016/j.bushor.2009.09.003.

[86] Happonen, A., Manninen, L., Hirvimäki, M., Nolte, A. (2021), Expectations for young job applicant's digital identity related to company's social media brand development strategies., Small Enterprise Research, https://doi.org/10.1080/13215906.2021.2000482.

[87] Dwivedi, Y.K., Kapoor, K.K., Chen, H. (2015), Social media marketing and advertising, The Marketing Review, Vol. 15, No. 3, pp. 289-309, https://doi.org/10.1362/146934715X14441363377999.

[88] Erkmen, E. (2018), Managing Your Brand for Employees: Understanding the Role of Organizational Processes in Cultivating Employee Brand Equity, Administrative Sciences, Vol. 8, Iss. 3, pp. 1-15, https://doi.org/10.3390/admsci8030052.

[89] Law, J. (1992), Notes on the theory of the actor-network: ordering, strategy, and heterogeneity, Systems Practice, Vol. 5, Iss. 4, pp. 379-393, https://doi.org/10.1007/BF01059830.

[90] Braga, C., Suarez, M. (2018), Actor-network theory: new perspectives and contributions to consumption studies, Cadernos EBAPE.BR, Vol. 16, No. 2, p. 218-231, https://doi.org/10.1590/1679-395164275.

[91] Happonen, A., Santti, U., Auvinen, H., Räsänen, T., Eskelinen, T. (2020), Digital age business model innovation for sustainability in University Industry Collaboration Model, E3S Web of Conferences, Vol. 211, Article 04005, pp. 1-11, https://doi.org/10.1051/e3sconf/202021104005.

[92] Salmela, E., Happonen, A., Hirvimäki, M., Vimm, I. (2015), Is Time Pressure an Advantage or a Disadvantage for Front End Innovation - Case Digital Jewelry, Journal of Innovation Management, Vol. 3, No. 4, pp. 42-69, https://doi.org/10.24840/2183-0606 003.004 0005.

[93] Happonen, A., Tikka, M., Usmani, U. (2021), A systematic review for organizing hackathons and code camps in Covid-19 like times: Literature in demand to understand online hackathons and event result continuation, In 2021 International Conference on Data and Software Engineering (ICoDSE), pp. 1-6

[94] Ghoreishi, M., Happonen, A. (2022), The Case of Fabric and Textile Industry: The Emerging Role of Digitalization, Internet-of-Things and Industry 4.0 for Circularity, Lecture Notes in Networks and Systems, Vol. 216, pp. 189-200, https://doi.org/10.1007/978-981-16-1781-2 18.

[95] Santti, U., Happonen, A., Auvinen, H., Räsänen, T., Eskelinen, T. (2020), Sustainable Business Model Innovation for Digital Remote Monitoring: A Follow up Study on a Water Iot Service, BIOS Forum 2020, St. Petersburg, Russia, 10/2020, pp. 1-7.

[96] Santti, U., Happonen, A., Auvinen, H. (2020), Digitalization Boosted Recycling: Gamification as an Inspiration for Young Adults to do Enhanced Waste Sorting, AIP Conference Proceedings, Vol. 2233, Iss. 1, p. 1-12, https://doi.org/10.1063/5.0001547.

[97] Ghoreishi, M., Happonen, A. (2020), New promises AI brings into circular economy accelerated product design: a review on supporting literature, E3S Web Conf., eISSN: 2267-1242, Vol. 158, pp. 1-10, https://doi.org/10.1051/e3sconf/202015806002.

[98] Happonen, A., Laplaza Osta, I., Potdat, A., Garcia-Alcaraz, J.L. (2021), Financially Feasible and Sustainable - Reviewing Academic Literature on Sustainability related Investment Studies, 1st edition, Book publisher International, pp. 1-43, https://doi.org/10.9734/bpi/mono/978-93-5547-032-4. 